\title{
座位における頸部および体幹の前額面上姿勢が 自覚的視性垂直位に与える影響
}

\author{
Frontal Posture of the Neck and Trunk in Sitting Influences Subjective Visual Vertical
}

\author{
藤本 修平 $^{1)}$ 藤本 静香 $^{2)}$ 小林 資英 $^{3)}$ 大高 洋平 ${ }^{1,4}$ \\ Shuhei FUJIMOTO ${ }^{1)}$, ShizUKa FUJIMOTO ${ }^{2)}$, MотоHide KOBAYASHI ${ }^{3)}$, Yohei OTAKA ${ }^{1,4)}$ \\ ${ }^{1)}$ Tokyo Bay Rehabilitation Hospital: 4-1-1 Yatsu, Narashino-City, Chiba 275-0026, Japan. TEL+81 47-453-9000 \\ E-mail: shuheifujimotomarty@yahoo.co.jp \\ ${ }^{2)}$ Tokyo Metropolitan Geriatric Hospital \\ ${ }^{3)}$ Kohno Clinical Medicine Research Institute, North Shinagawa Hospital \\ 4) Department of Rehabilitation Medicine, Keio University School of Medicine
}

Rigakuryoho Kagaku 28(3): 407-410, 2013. Submitted Dec. 25, 2012. Accepted Jan. 22, 2013.

\begin{abstract}
Purpose] To investigate whether postures of the head and trunk in the frontal plane affect the subjective visual vertical (SVV). [Subjects] Nineteen healthy adults were enrolled. [Methods] We measured SVV under five sitting conditions: upright, inclining the head, inclining the trunk, inclining the trunk with the head upright, inclining both the head and trunk. Subjects were instructed to stop a moving line on a PC monitor when they thought that the line was vertical. The values of SVV, and the differences in degree between the true vertical and subjective vertical, were compared among the five conditions. [Results] The absolute values of SVV in the upright and inclining the trunk with the head upright conditions were significantly smaller than those in the three other conditions. The values of SVV in the inclining the trunk condition was significantly smaller than those in the inclining the head or in inclining the head and trunk conditions. [Conclusions] The effects of posture on SVV measurement must be considered.
\end{abstract}

Key words: subjective visual vertical, sitting conditions, frontal plane

要旨：〔目的〕健常者において，頭頸部・体幹の前額面上の座位姿勢がSVVに影響するか検討した。〔対象〕健常 者 19 名（男性 11 名, 女性 8 名）とした。〔方法〕座位姿勢は 5 種類（正中位, 頸部側屈位, 身体傾斜位, 立ち直り 位, 最大傾斜位) とした. SVVは, PC 上で動く線分を垂直位と感じた時点で止めるように指示し, 測定した。 そして, 真の垂直線との角度差を符号付きおよび絶対值 SVV 度として算出し, 姿勢間の差を検討した.〔結果〕正中位およ び立ち直り位の絶対值 SVV 度の大きさは，その他の姿勢の場合の值より有意に小さかった，また，身体傾斜位の絶 対值 SVV 度の大きさは，頸部側屈位および最大傾斜位の值より有意に小さかった。〔結語〕前額面上の姿勢変化は SVVに影響するため, 姿勢の規定が必要であると考える.

キーワード : subjective visual vertical, 座位姿勢, 前額面

1) 医療法人社団保健会＼cjkstart東京湾岸リハビリテーション病院リハビリテーション科:千葉県習志野市谷津 4-1-1 ( TEL 047-453-9000

2) 地方独立行政法人東京都健康長寿医療センター

${ }^{3)}$ 財団法人河野臨床医学研究所 北品川病院

4) 慶應義塾大学 医学部 リハビリテーション医学教室

受付日 2012年12月25日＼cjkstart受理日２013年1月22日 


\section{I.はじめに}

目的動作を効率よく達成するためには，状況変化に合 わせた姿勢の変換と保持が必要であり 1$)$, 前庭感覚系や 視覚系, 体性感覚系といったさまざまな感覚系をするこ とで 2,3)，状況変化と姿勢を協調的に結びつけている.

感覚系を総合的に評価する方法のひとつとして，自覚 的視性垂直位 (Subjective Visual Vertical; 以下, SVV) 検查がある ${ }^{4}$. SVVは，視覚で捉える空間的垂直位と実 質的な垂直位のズレを評価するものであり 5,6)，感覚系 の機能障害やバランス能力を評価するために用いられる ことがある7)。また，座位や立位に抒ける運動制御にも 関係するとされ，臨床に扔ける姿勢の評価として有用で あることが示唆されている ${ }^{8-10)}$. SVVの従来の標準的な 測定は，頭頸部，体幹をできるだけ垂直位にした状態で， 画面上に映る動く直線が重力線に対して平行となった時 点を, 自覚的に判断する方法で行われる11-13).

脳卒中患者, とりわけ視覚的な垂直位や身体認識に障 害を持つ患者は, 臨床上, 日常生活に扔ける姿勢は左右 非対称であり ${ }^{14)}$ ，重症度が増すにつれその非対称性は 大きくなる，頭頸部，体幹は同方向に傾斜することもあ れば，頭頸部，体幹がそれぞれ別方向に傾斜している場 合もある。このような非対称性を有した姿勢に㧍ける感 覚情報が，SVVにどのように影響するかを検討するこ とは意義があると考えられる。これまでに，側臥位では SVVは傾斜方向と逆方向に, 12 から 21 度の偏位が見ら れることが報告されている ${ }^{15,16)}$ 。また，体幹，頸部を それぞれ個別に傾斜させた場合に，頸部のみを傾斜させ た時の方が，SVVの偏位がより大きくなることも報告 されている17).

しかし, 先行研究 13,18-22)では, 頸部と体幹の姿勢の 組み合わせを規定し，SVVへの影響を検討したものは 見当たらず，実際に脳卒中患者でみられるような日常的 な姿勢がどのように影響するかについてはわかっていない． そこで，健常者において，座位に打ける頭頸部および体 幹の前額面上の姿勢がSVVにどのように影響するかに ついて検討を行った.

\section{II. 対象と方法}

\section{1. 対象}

神経疾患, 運動器疾患, 耳鳴り, 難聴, 眩暈を有さな い健常者 19名（男性11名, 女性 8名, 23 32歳, 平均 年齢 $26.9 \pm 2.1$ 歳）を対象とした。近視や乱視のある対 象者には，眼鏡またはコンタクトレンズを使用した状態 で測定を行なった，対象者には、ヘルシンキ宣言に基づき， 本研究の内容を十分に説明し書面にて同意を得た.
2. 方法

規定した姿勢は 5 種類とし，空間的な各部位の位置関 係から，(1)正中位（頸部 0 度・体幹 0 度位），(2)頸部側屈 位(頸部 20 度側屈位·体幹 0 度側屈位), (3)身体傾斜位(頸 部 0 度側屈位・体幹 20 度側屈位), (4)立ち直り位（頸部 -20 度側屈位・体幹 20 度側屈位), (5)最大傾斜位（頸部 20 度側屈位・体幹 20 度側屈位）とした。これらの姿勢 は自作の器具で規定し，実験中の体動を極力減らすよう に，布製ベルトにて固定した，測定姿勢の頸部および体 幹の傾斜は以下の通りに規定した。頸部傾斜は，第7頸 椎棘突起と第 1 仙骨との棘突起を結ぶ線を基本軸とし, 後頭隆起と第 7 頸椎棘突起を結ぶ線を移動軸としたとき のそれらが為す角度，身体傾斜では，Jacoby線の中点 に立てた垂直線を基本軸とし，第 7 頸椎棘突起と第 5 腰 椎棘突起を結ぶ線を移動軸としたときのそれらが為す角 度とした。後頭隆起部, 第 7 頸椎棘突起, 第 1 仙骨部に 直径 $2 \mathrm{~cm}$ のマーカーを貼り付け, ゴニオメーター（MINATO 社製，ワイド角度計）を使用し, 角度を確認した後に SVV 測定を行った

SVVの測定方法においては，SVVの評価用自作器具 の前で対象に椅座位をとらせた。自作器具はパーソナル コンピューター(以下， PC) とその周辺視野を遮るために， 顔面を覆うことができるように穴を開けた自作器具（縦 $32 \mathrm{~cm} \times$ 横 $50 \mathrm{~cm} \times$ 高さ $35 \mathrm{~cm}$ ) を作成した。 また, 頸 部が前屈しないようにする為に, 筒（直径 $24 \mathrm{~cm} \times$ 高さ $14 \mathrm{~cm}$ ）を取り付けた，筒には目の高さ，位置の設定を するためのマーカーを付けた，顔より約 $50 \mathrm{~cm}$ 前方に液 晶モニターを設置し，モニター上に $18 \mathrm{~cm} \times 0.5 \mathrm{~cm}$ の線 分を表示した，自作器具は, 高さの調節できる台の上に 設置し，筒に付けたマーカーと合うように台の高さの調 節を行なった，PC上に表示された線分は，右または左 に60度傾斜した位置に提示され，20度/secで反対側の 同位置まで動くように設定した，対象者にはPCを右手 で操作させ，この線分が垂直位となった時点で主観的に 止めるように指示した，線分の静止後，対象者に調節を 行わせ，主観的な垂直位を決定させた。弧を描くように 動く線分は, 左右交互に提示され, 測定は各々左右で各 2 回ずつ, 計4回測定した。また外部環境の影響を少な くするために，実験は静かな暗室で実施した，測定手順 は循環法に基づき行なった。解析は，対象者が垂直位を 判断した時点の線分の傾きをグラフィックソフト Canvas8(日本ポラデジタル社製)で計算し, 得られたデー 夕と真の垂直位の差 (以下，符号付き SVV 度：傾斜側を 正とした）を算出した。次にその絶対值（以下, 絶対值 SVV 度) を求め, 左右各 2 回の平均值士標準誤差を採用 した. 平均值の小数点第 2 以降は, 四捨五入を行った. 測定手順は循環法に基づいて行った。

統計解析は各姿勢間のSVV 度を比較するために, Shaffer法で $\alpha$ エラーを補正した後に対応のあるt検定を 
行った．統計ソフト R Version2.8.1(フリーソフト)を用い 有意水準は $5 \%$ 未満とした.

\section{III. 結 果}

符号付きSVV度は，正中位で- $0.1 \pm 0.16$ 度，頸部側 屈位で $-0.3 \pm 0.22$ 度, 身体傾斜位で $-0.3 \pm 0.21$ 度, 立ち直り位で $0.1 \pm 0.18$ 度, 最大傾斜位で $-0.3 \pm 0.25$ 度であった。各姿勢間の比較において, 統計的に有意差 は認められなかった (表1).

絶対值 SVV 度は, 正中位で $1.1 \pm 0.11$ 度, 頸部側屈位 で $2.2 \pm 0.12$ 度, 身体傾斜位で $1.8 \pm 0.10$ 度, 立ち直り 位で $1.2 \pm 0.11$ 度, 最大傾斜位で $2.4 \pm 0.16$ 度であった。

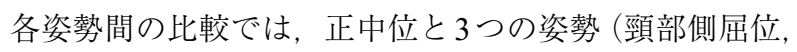
身体傾斜位，最大傾斜位，いずれも $\mathrm{p}<0.01 ）$ の間で，立 ち直り位と 3 つの姿勢（頸部側屈位，身体傾斜位，最大 傾斜位，いずれも $\mathrm{p}<0.01 ）$ の間に有意差が認められた。 また，頸部側屈位と身体傾斜位（ $\mathrm{p}<0.01 ）$, 頸部側屈位 と最大傾斜位および最大傾斜位 $(\mathrm{p}<0.01)$ ，および，身 体傾斜位と最大傾斜位 $(\mathrm{p}<0.05)$, の間で有意差が認め られた。正中位と立ち直り位 $(\mathrm{p}=0.44)$ の間，および, 最大傾斜位と頸部側屈位 $(\mathrm{p}=0.44)$ の間に有意差は認め られなかった(表1).

\section{IV. 考 察}

本研究の結果から, 健常者において, 前額面上の座位 の姿勢変化は, 絶対值 SVV 度のみに認められ, 符号付 きSVV度では認められなかった。符号付きSVV度につ いて，側臥位の姿勢，つまり空間的に頸部を 90 度傾け た状態において, 傾斜側と逆方向へ 12 度のずれが認め られており15)，また，10度程度の傾きでは傾斜側と同 方向へ約 1 度のずれが報告されている17)。本研究では頸 部を空間的に最大で 40 度傾けているが，ずれは少なかっ た.このことから, 空間的にかなりの傾斜を条件としな い限り，符号付きSVV度に影響しないことが示唆された。 符号付きSVV度と絶対值 SVV 度の関係については, 脳 卒中片麻痺患者を対象とした研究において, 符号付き
SVV 度, 絶対值 SVV 度はそれぞれ-0.3 2 2.3 度, 2.0 \pm 1.5 度と報告があったが, 絶対值 SVV 度のずれが大き い結果であった ${ }^{13)}$ ，すなわち，垂直性を判断する機能の 低下した状態, または今回の研究のように垂直性を判断 する機能を乱すような条件では, SVV度のずれは方向 よりも大きさに影響があると考えられる。

符号付きSVV 度と絶対值 SVV 度の指標はそれぞれ性 質上で異なるものである。絶対值は数学的に軽微な変化 も捉えやすく, 本研究や先行研究13)においても, 符号 付き SVV 度と比較し絶対值 SVV 度に相違が見られたこ とは，この性質によることもひとつの理由であろう。

姿勢別の影響については, 頸部側屈位, 身体傾斜位, 最大傾斜位, すなわち, 頸部が空間的に重力線に対して 垂直でなく，傾いている姿勢において，絶対值 SVV 度 の大きなずれが認められた。健常者において，SVV度 のずれは, 若年健常者で土 1 度, 健常者で \pm 2.5 度とさ れ7,11), 本研究の結果も正中位は 1 度程度であったが, 頸部側屈位, 身体傾斜位, 最大傾斜位はそれを大きく上 回っていた。このずれの要因として, 頭部の傾斜角度が 影響していることが考えられる．SVVは前庭感覚機能 検査として用いられている11)。 また, 頭部を傾斜させ ると耳石器の感受性が低下するとの報告がある ${ }^{23,24)}$ 。こ のことから, 頭部の空間的な位置によって前庭感覚入力 に変化が起こり, SVVが偏位したのではないかと考える. 頸部の絶対的な傾斜角度が等しい頸部側屈位と身体傾 斜位に有意差が認められ，そして，絶対的傾斜角度が異 なる頸部側屈位と最大傾斜位に有意差を認めなかった。 前者の理由は, 体幹に対する頸部の側屈, すなわち相対 的な頸部の傾斜があげられる。体幹に対する頸部の側屈

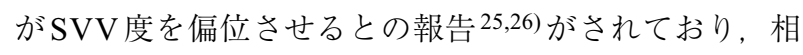
対的な頸部の傾斜が影響したと推察される。しかし, 後 者は, 相対的な頸部の傾斜については同じ条件であり, このことは理由にはなり得ない. 他の可能性として, 測 定姿勢の規定として用いた板やベルトでの体幹, 頸部の 固定の影響が挙げられる. 固有感覚がSVVに影響する との報告があり 27,28), 頸部, 体幹の傾斜がより強い, 最 大傾斜位の測定時に, 頸部側屈位よりも体性感覚として 触圧覚の情報入力量が多かったことが影響を及ぼしたこ

表1 各姿勢のSVV度とその比較結果

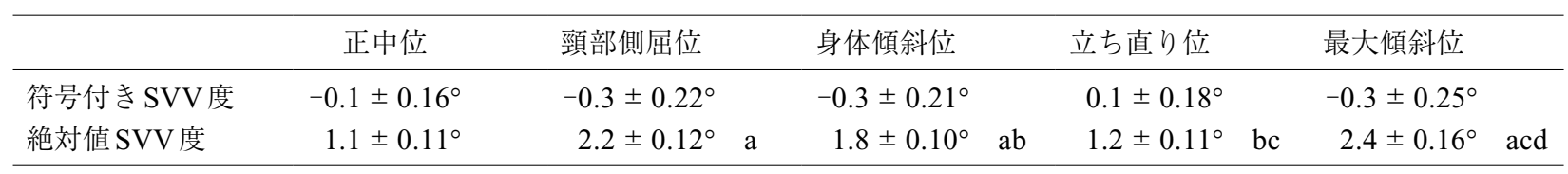

Mean $\pm \mathrm{SD}^{\circ}$

$\mathrm{a}$ ：絶対值 SVV 度における，正中位に対して有意差あり $(\mathrm{p}<0.01)$

$\mathrm{b}$ ：絶対值 SVV 度における, 頸部側屈位に対して有意差あり $(\mathrm{p}<0.01)$

$\mathrm{c}$ ：絶対值 SVV 度における，身体傾斜位に対して有意差あり $(\mathrm{p}<0.05)$

$\mathrm{d}$ ：絶対值 SVV 度における, 立ち直り位に対して有意差あり $(\mathrm{p}<0.01)$ 
とが予測されるが，本研究における姿勢の規定上必要で あったため, 本研究の限界であると考える.

本研究により，座位における頸部および体幹の前額面 上の姿勢によって，SVVは変化することが示され，頸部 側屈位のような比較的に小さい変化でも, 大きく SVV が変化することが明らかとなった，そのため，脳卒中患 者のような, 日常生活において非対称性の姿勢をとる者 を対象とする場合のSVV検査では, 検査中の頸部(頭部) , 体幹が傾斜しない姿勢をとるように規定し，可能な限り ずれを小さくする必要性が挙げられた。さらに，非対称 性の姿勢におけるSVVの検査も行い, その経時的な変 化を追うことで実質的な日常生活への影響程度を把握す ることができる可能性がある.

\section{引用文献}

1) 舩冨卓哉, 美濃導彦：さまざまな姿勢での光切断法による 三次元人体形状モデリング。情報処理学会研究報告, 2007 , $42: 233-248$.

2) 佐直信彦, 中村隆一：脳卒中片麻疩患者の立位バランスの 決定因.リハビリテーション医学, 1993, 30(6)：339-403.

3) Lee DN, Aronson E: Visual proprioceptive control of standing in human infants. Attention, Perception, \& Psychophysics, 1974, 15(3): 529-532.

4) 増田圭奈子, 斎藤 晶, 神崎 仁·他：自覚的視性垂直位 (SVV) 検查の測定条件について一特に視標の位置と視覚条 件の影響一. Equilibrium Res, 2003，62(3): 181-189.

5) 西村由香, 吉尾雅春, 松本博之 - 他 : 脳卒中患者の自覚的 視性垂直位一Pushing 現象と半側空間無視に着目した自覚 的視性垂直位の特徵一. 理学療法学, 2011, 38(7): 516-523.

6) 沼田憲治, 齋藤 宏, 萩原 昇・他：重心動摇からみた脳 損傷患者の視覚影響. 理学療法学, 1989, 16(4): 231-235.

7) Bonan V, Hubeaux K, Gellez-Leman MC, et al.: Influence of subjective visual vertical misperception on balance recovery after stroke. J Neurol Neurosurg Psychiatry, 2007, 78(1): 49-55.

8) 大隈 統, 網本 和, 高倉保幸・他 : 脳血管障害例の座位 姿勢制御における視覚的垂直定位の影響. 理学療法科学, 2006, 21(3): 261-265.

9) 内田全城, 丸山仁司：視線行動に伴う立位頸部回旋位が 自覚的視性垂直定位に与える影響. 理学療法科学, 2012, 27(3): 351-354.

10) 内田全城：視覚指標提示角度の定位付け条件が立位重心動 摇に与える影響一水平面上視線行動に伴う身体回旋運動か らの検証一. 理学療法科学, 2012, 27(2)：181-184.

11) 國弘幸伸：自覚視性垂直位（SVV)。 Equilibrium Res, 2004 , 63(6): 533-548.

12) 西村由香, 吉尾雅春, 松本博之 - 他: 脳卒中患者の自覚 的視性垂直位一Pushing 現象と半側空間無視に着目した
自覚的視性垂直位の特徵一. 理学療法学, 2011，38(7), 516-523.

13) 當山隆道, 大高洋平, 荒木泰智・他：脳卒中患者におけ る自覚的視性垂直位と静止立位時バランスとの関連. The Japanese Journal of Rehabilitation Medicine, 2011，48(4): 263-269.

14) 笠原敏史, 戸塚満久, 高橋光彦 - 他 : 非対称性体幹前屈 運動時の屈曲弛緩現象について。理学療法科学, 2010, 25(1): 133-138.

15) Dyde RT, Jenkin MR, Harris LR: The subjective visual vertical and the perceptual upright. Exp Brain Res, 2006, 173: 612-622.

16) Mittelstaedt $\mathrm{H}:$ The subjective vertical and the sense of self orientation during active body tilt. Vision Research, 2001, 41: 3229-3242.

17) Wade NJ : Visual orientation during and after lateral head,body,and trunk tilt. Perception and Psychophysics, 1968, 3(3B): 215-219

18) 松崎真樹, 室伏利久：携帯型自覚的視性垂直位測定装置 の開発一従来型（固定型）装置との比較. Equilibrium Res, 2010, 69(6): 432-436.

19) 小川恭生, 清水重敬, 大塚康司 - 他 : 前庭神経炎, 突発 性難聴における自覚的視性垂直位所見. Equilibrium Res, 2009, 68(2): 85-91.

20) 中川 肇，渡辺行雄：めまい症例に扔ける空間識の認識機 能一正常人と末梢前庭障害における自覚的視性垂直位の比 較検討一. Equilibrium Res, 1998, 57(1): 69-74.

21) 小林宏成, 五島史行, 國弘幸伸・他：回旋性視覚刺激下の 自覚的垂直位（Subjective Visual Vertical：SVV）と vection. Equilibrium Res, 2005, 64(2): 57-63.

22) 稲垣太郎, 湯川久美子, 市村彰英・他：内耳疾患の経過 中に発症したBPPV様症候の検討. Equilibrium Res, 2008, 67(1): 18-23.

23) 高橋正紘: 平衡制御に占める前庭神経核の役割. Equilibrium Res, 2008, 67(3): 170-181.

24) Templeton WB : The role of gravitational cues in the judgment of visual orientation. Perception \& Psychophysics, 1973, 14(3): 451-457.

25) 和田佳郎：宇宙で傾きは存在するか? 一国際宇宙ステー ション長期宇宙滞在中に㧍ける空間識実験計画の紹介一. Equilibrium Res, 2011, 70(2): 115-121.

26) Keusch S, Hess BJ, Jaggi-Schwarz K: Direction specific error patterns during continuous tracking of the subjective visual vertical. Exp Brain Res, 2004, 155: 283-290.

27) Faralli M, Longari F, Ricci G, et al.: Influence of extero- and proprioceptive afferents of the plantar surface in determining subjective visual vertical in patients with unilateral vestibular dysfunction. ACTA Otorhinolaryngol Ital, 2009, 29: 245-250.

28) Beuzekom AD, Medendorp WP, Gisbergen JA: The subjective vertical and the sense of self orientation during active body tilt. Vision Research, 2001, 41: 3229-3242. 